\title{
PENINGKATAN KREATIVITAS DAN HASIL BELAJAR IPA MELALUI MODEL PEMBELAJARAN KOOPERATIF TPS PADA KONSEP CAHAYA KELAS VIII B SEMESTER 2 SMPN1 JAMBU TAHUN PELAJARAN 2012/2013
}

\author{
Bambang Eko Purnomo \\ SMP Negeri 1 Jambu \\ bambang_ekopurnomo@yahoo.com
}

\begin{abstract}
ABSTRAK
Tujuan penelitian ini adalah untuk (1) meningkatkan kreativitas belajar dan (2) meningkatkan hasil belajar IPA peserta kelas VIII B SMP Negeri 1 Jambu Kabupaten Semarang melalui model pembelajaran kooperatif Tipe Think, Pair, Share(TPS) pada pembelajaran IPA semester 2. Penelitian ini merupakan penelitian tindakan kelas dengan 2 siklus, dengan tiap siklus terdiri atas perencanaan, pelaksanaan tindakan, observasi dan refleksi. Subyek penelitian ini adalah peningkatan kreativitas dan hasil belajar. Sumber data berasal dari peserta didik, hasil observasi, wawancara dan dokumentasi. Teknik pengumpulan data adalah dengan observasi, test, dokumentasi, dan angket. Validasi data menggunakan teknik kualitatif dan kuantitatif. Analisis data adalah deskriftif kualitatif dengan menggunakan teknik analisis model interaktif melalui hasil wawancara, observasi, angket, jurnal kelas dan dokumentasi.

Berdasarkan hasil penelitian dapat disimpulkan bahwa kreativitas dan hasil belajar peserta didik dalam pembelajaran IPA di kelas VIII B SMP Negeri 1 Jambu mengalami peningkatan setelah menggunakan model pembelajaran TPS. Peningkatan kreativitas peserta didik dapat diketahui dari hasil observasi yang dilaksanakan pada akhir siklus 1 dan siklus 2 menunjukkan peningkatan skor rata-rata kreativitas peserta didik dari 66,4 pada siklus 1 menjadi 81 pada siklus 2. Sedangkan peningkatan hasil belajar dapat diketahui dari hasil ulangan pra siklus dengan rata-rata 72,2 menjadi 74,4 pada siklus 1 dan 80,5 pada siklus 2 .
\end{abstract}

Kata kunci: pembelajaran kooperatif, kreativitas, dan hasil belajar.

\section{PENDAHULUAN}

Tujuan pembelajaran IPA di sekolah adalah untuk memberikan pengetahuan guna memahami konsep-konsep IPA dan keterkaitannya, serta mampu menerapkannya dengan metode ilmiah yang melibatkan ketrampilan proses untuk memecahkan masalah dalam kehidupan sehari-hari. Selain itu, pengajaran IPA diharapkan mampu meningkatkan kesadaran peserta didik terhadap perkembangan ilmu pengetahuan dan teknologi. Keberhasilan pengajaran tersebut salah satunya bergantung pada guru dalam merencanakan pembelajaran di sekolah dan kesiapan peserta didik dalam mengikuti pembelajaran.

Namun demikian masih ada 8 dari 32 anak kelas VIIIB yang belum tuntas belajar. Banyak faktor yang menyebabkan prestasi belajar IPA rendah, antara lain: (1) Guru selalu menggunakan metode ceramah, (2) Guru bertindak otoriter, (3) Peserta didik tidak aktif dalam mengikuti pembelajaran, (4) Peserta didik tidak bersemangat, karena pembelajaran kurang menarik.

Dengan melihat kenyataan tersebut faktor guru juga berperan dalam pembelajaran di kelas. Oleh karena guru harus berani mencoba mencari model pembelajaran yang sesuai dengan konsep yang akan 
diajarkan yaitu menggunakan pembelajaran TPS. Langkah-langkah teknik TPS adalah melatih peserta didik dalam berpikir, dan merespons serta salaing membantu, meningkatkan kemampuan peserta didik dalam mengingat suatu informasi dan dapat menyampaikan idenya dalam diskusi, membantu memecahkan masalah, membuat kesimpulan, dan mempresentasikan hasil diskusi, meningkatkan kebaikan budi, kepekaan, dan toleransi peserta didik, belajar berempati, menerima pendapat orang lain. Berdasarkan uraian tersebut timbul permasalahan (1) berapa besar peningkatan kreativitas siswa konsep cahayadengan model pembelajaran kooperatif TPS kelas VIII B semester II SMP Negeri 1 Jambu tahun ajaran 2012/2013, (2) berapa besar peningkatan belajar IPA konsep cahaya dengan model pembelajaran kooperatif TPS kelas VIII B semester II SMP Negeri 1 Jambutahun ajaran 2012/2013.

\section{METODE PENELITIAN}

Penelitian pada tindakan kelas ini adalah kelas VIII B semester II SMP Negeri 1 Jambu Kabupaten Semarang tahun pelajaran 2012/2013 dan obyek penelitiannya adalah kreatifitas dan hasil belajar peserta didik. Penelitian Tindakan Kelas ini dilakukan dalam 2 siklus, dimana dalam setiap siklus dilakukan kegiatan perencanaan, tindakan, observasi, dan refleksi. Intrumen yang digunakan adalah lembar observasi dan tes hasil belajar.

\section{HASIL PENELITIAN DAN PEMBAHASAN}

\section{Hasil Penelitian}

Hasil penelitian tindakan kelasi nid iperoleh dari tindakan prasiklus yaitu pretes, kemudian hasil tes siklus I, dan hasil tes siklus II. Hasil pretes berupa perolehan nilai sebelum menggunakan model kooperatif tipe TPSd alam pembelajaran. Begitu pula hasil tes tindakan siklus I dan siklus II berupa hasil tes yang dilakukan setelah pembelajaran selesai.

Sedangkan hasil non tes berupa perubahan perilaku peserta didik selama proses pembelajaran, meliputi keaktifan, keseriusan, kepercayaan diri, kerja sama, kedisiplinan dan tanggung jawab, kekritisan, serta kemampuan melakukan presentasi. Data mengenai mengenai tersebut didapatkan melalui instrumen non tes, yaitu observasi, angket, jurnal kelas, jurnal guru, wawancara, dan dokumentasi foto.

\section{Hasil Tes Prasiklus/Pretes}

Sebelum pretes dilaksanakan, terlebih dulu peneliti menyampaikan apersepsi yang bertujuan memberi gambaran pada peserta didik tentang tes yang akan dilaksanakan. Hasil tes pada pra siklus dari peserta didik dikelompokkan dalam Tabel 1.

Tabel 1. Hasil Ulangan Harian Kondisi Awal/Pretes/Prasiklus 


\begin{tabular}{|c|c|c|c|c|}
\hline No & Rentang Nilai & $\mathbf{F}$ & Prosentase & Keterangan \\
\hline 1 & $95-100$ & - & - & Dari data disamping dapat \\
\hline 2 & $90-94$ & 3 & 9,75 & disimpulkan bahwa dengan \\
\hline 3 & $85-89$ & 4 & 12,50 & KKM IPA 75, maka kelas \\
\hline 4 & $80-84$ & 5 & 15,60 & VIII B yang memiliki rata- \\
\hline 5 & $75-79$ & 8 & 25,00 & rata UH pra siklus 72,2 , \\
\hline 6 & $70-74$ & - & - & maka dapat diartikan belum \\
\hline 7 & $65-69$ & 4 & 12,50 & ketuntasan \\
\hline 8 & $60-64$ & 3 & 9,75 & maksimal \\
\hline 9 & $55-59$ & 1 & 3,12 & \\
\hline 10 & $50-54$ & 2 & 6,25 & \\
\hline 11 & $45-49$ & 1 & 3,12 & \\
\hline 12 & $40-44$ & 1 & 3,12 & \\
\hline \multirow[t]{5}{*}{13} & $35-39$ & - & & \\
\hline & Jumlah & 32 & & \\
\hline & Nilai Tertinggi & 90 & & \\
\hline & Nilai Terendah & 40 & & \\
\hline & Nilai Rerata & 72,2 & & \\
\hline
\end{tabular}

Hasil belajar IPA kelas VIII B pada semester II "Memahami konsep dan penerapan getaran dan optika dalam produk teknologi sehari-hari”. Dari 32 peserta didik yang mengikuti ulangan harian pra siklus yang mendapatkan nilai sama dengan atau lebih besar dari KKM mata pelajaran IPA adalah 20 peserta didik atau 62,5\% yang tuntas, sedangkan masih terdapat 12 peserta didik yang belum tuntas yaitu $37,5 \%$.

Sedangkan kreativitas belajar IPA pada pra siklus dapat dilihat dari keadaan proses pembelajaran yang telah didokumentasikan berikut ini.

Dari kegiatan diatas terlihat bahwa peserta didik hanya melakukan apa yang diperintah oleh guru, mencatat, diam dan mendengarkan apa yang di ucapkan oleh guru, sehingga suasana kelas terlihat tenang, seperti tidak ada aktivitas. Hal ini sangat tidak diharapkan dalam proses belajar mengajar, artinya hampir $100 \%$ peserta didik dalam mengikuti pembelajaran berlaku pasif.

Selain pretes peneliti juga menerapkan metode wawancara yang dilakukan terhadap beberapa peserta didik kelas VIII B secara acak yaitu ada yang memperoleh nilai kurang, nilai sedang atau nilai baik. Dari hasil wawancara tersebut, diketahui bahwa peserta didik merasa bosan, pelajaran kurang menarik, sehingga mengantuk dalam kelas sehingga rata-rata peserta didik pasif dalam mengikuti pembelajaran.

\section{Hasil PenelitianSiklusI}

\section{HasilTes SiklusI}

Penilaian tes siklus I dilaksanakan pada setiap akhir pembelajaran Hasil tes pada tindakan pembelajaran siklus I dapat dilihat dalam Tabel 2. 


\begin{tabular}{|c|c|c|c|c|}
\hline No & Rentang Nilai & $\mathbf{F}$ & Prosentase & Keterangan \\
\hline 1 & $95-100$ & - & - & Dari data disamping dapat \\
\hline \multirow[t]{2}{*}{2} & $90-94$ & 1 & 3,12 & disimpulkan bahwa dengan \\
\hline & $85-89$ & 5 & 15,6 & KKM IPA 75, maka kelas \\
\hline 4 & $80-84$ & 8 & 25,0 & VIII B yang memiliki rata- \\
\hline 5 & $75-79$ & 9 & 28,1 & rata $\mathrm{UH}$ siklus $\mathrm{I}=74,4$ \\
\hline 6 & $70-74$ & - & - & maka dapat diartikan ada \\
\hline 7 & $65-69$ & 4 & 12,5 & kenaikan rata-rata nilai \\
\hline 8 & $60-64$ & 3 & 9,37 & ulangan, walaupun masih di \\
\hline 9 & $55-59$ & 2 & 6,25 & bawah KKM mata pelajaran \\
\hline 10 & $50-54$ & - & & IPA \\
\hline 11 & $45-49$ & - & & \\
\hline 12 & $40-44$ & - & & \\
\hline \multirow[t]{5}{*}{13} & $35-39$ & - & & \\
\hline & Jumlah & 32 & & \\
\hline & Nilai Tertinggi & 90 & & \\
\hline & Nilai Terendah & 55 & & \\
\hline & Nilai Rerata & 74,4 & & \\
\hline
\end{tabular}

Hasil tes pada siklus I kelas VIII B pada pelajaran IPA mengalami kenaikan rata-rata , dari 72,2 pada siklus I menjadi 74,4 berarti ada kenaikan sebesar 2, 2 atau 3,04\%. Dari 32 peserta didik yang mengikuti ulangan harian atau tes akhir sikllus I yang tuntas ada 23 peserta didik atau 71,8\%, sedangkan masih ada 9 peserta didik atau 28,2\% yang masih belum tuntas. Hasil tersebut sudah dapat menggambarkan bahwa ada kenaikan hasil belajar peserta didik dengan menggunakan model kooperatif Think, pair, share (TPS).

Sedangkan kreativitas belajar IPA pada siklus I dapat dilihat dari keadaan proses pembelajaran yang telah didokumentasikan berikut ini.

Dari kegiatan diatas terlihat bahwa peserta didik mulai tidak canggung, percaya diri, dan tidak malu untuk melakukan presentasi di depan kelas yaitu menyampaikan hasil diskusi yang telah dilakukan oleh kelompoknya masing-masing. Hal inilah yang diharapkan oleh setiap guru agar dalam proses belajar mengajar selalu ada timbal balik artinya peserta didik menjadi aktif berani mengemukakan pendapatnya.

\section{Hasil Nontes Siklus I}

Data penelitian hasil nontes siklus I didapat dari hasil observasi, angket, jurnal kelas, jurnal guru, wawancara, dan dokumentasi foto.

\section{Hasil Observasi}

Hasil observasi siklusI terdapatdapat dilihat pada Tabel 3.

Tabel 3. Hasil Observasi Kreativitas Belajar IPA Siklus I 


\begin{tabular}{lcccc}
\hline \multicolumn{1}{c}{ Aspek } & Aktif & F & $\begin{array}{c}\text { Tidak } \\
\text { Aktif }\end{array}$ & F \\
\hline 1. Perhatian dan respon peserta didik & $73 \%$ & 23 & $27 \%$ & 9 \\
2. Aktif dalam diskusi & $63 \%$ & 20 & $37 \%$ & 12 \\
3. Aktif bertanya & $65 \%$ & 21 & $35 \%$ & 11 \\
4. Berani dan tidak canggung saat & $56 \%$ & 18 & $44 \%$ & 14 \\
$\begin{array}{l}\text { presentasi } \\
\text { Menghargai kelompok lain dalam }\end{array}$ & $75 \%$ & 24 & $25 \%$ & 8 \\
\hline
\end{tabular}

Dari tabel 3 terlihat bahwa perhatian respons peserta didik terhadap pembelajaran mencapai $73 \%$ atrau 23 peserta didik, dan yang tidak respons terhadap pembelajaran hanya $27 \%$ atau 9 peserta didik. Sedangkan keaktifan peserta didik dalam diskusi mencapai 63\% atau 20 peseta didik dan yang tidak aktif hanya diam atau mendengar saja mencapai $37 \%$ atau 12 peserta didik. Keberanian peserta didik bertanya dalam pelaksanaan diskusi mencapai $65 \%$ atau 21 peserta didik, sedangkan sisanya $35 \%$ atau 11 peserta didik tidak berani bertanya.

Dalam kegiatan diskusi pada siklus I ini masih sedikit sekali peserta didik yang berani dan tidak canggung saat presentasi. Hal ini terlihat hanya 56\% atau 18 peserta didik yang berani dan tidak canggung saat melakukan presentasi dan $44 \%$ atau 14 peserta didik tidak berani dan canggung dalam melakukan presentasi. Yang sedikit baik yang dilakukan peserta didik dalam diskusi adalah menghargai kelompok lain yang maju kedepan yaitu $75 \%$ atau 24 peserta didik sedangkan yang acuh atau tidak menghargai kelompok lain ada $25 \%$ atau 8 peserta didik.

\section{Hasil wawancara}

Hasil wawancara menunjukkan bahwa setelah peneliti menggunakan model kooperatif tipe think, pair, share dalam proses pembelajaran, perubahan perilaku peserta didik mulai tampak. Mereka mulai senang dan antusias dengan pembelajaran IPA. Dari hasil wawancara sebagian peserta didik, menunjukkan bahwa pembelajaran IPA menyenangkan.

\section{Hasil Angket}

Hasil angket pembelajaran siklus 1 berakhirdapat dilihat pada Tabel 4.

Tabel 4. Hasil Angket Tanggapan Peserta Didik Siklus I

\begin{tabular}{llllll}
\hline \multirow{2}{*}{ No } & \multicolumn{1}{c}{ Pernyataan } & \multicolumn{3}{c}{ Tanggapan peserta didik } \\
& SS & S & TS & TT \\
\hline & $\begin{array}{l}\text { Pembelajaran IPA dengan model kooperatif } \\
\text { tipe think, pair, share (TPS) seperti yang } \\
\text { sudah dilaksanakan sangat menarik dan } \\
\text { menyenangkan. }\end{array}$ & $62 \%$ & $38 \%$ & 0 & 0 \\
$\begin{array}{l}\text { Dengan pembelajaran model kooperatif } \\
\text { saya menjadi berani untuk maju, dan 68\% } \\
\text { bertanya tentang materi IPA. }\end{array}$ & & & & \\
& & & & & \\
\end{tabular}


Dengan pembelajaran model kooperatif saat dalam kelompok saya menjadi berani melakukan presentasi di depan teman$52 \% \quad 48 \% \quad 0 \quad 0$ teman sekelas.

Dengan pembelajaran model kooperatif

4 saya menjadi memiliki tanggung jawab ketika mengerjakan tugas baik sendiri atau berkelompok.

Saat ini saya sudah tidak lagi merasa malu atau takut untuk maju atau bertanya saat

Berdasarkan tabel 4. Bahwa pembelajaran IPA dengan model kooperatif tipe TPS seperti yang sudah dilaksanakan sangat menarik dan menyenangkan ada 62\% yang sangat setuju dan 38\% setuju, sedangkan dengan pembelajaran model kooperatif peserta didik menjadi berani untuk maju, dan bertanya tentang materi IPA yaitu $68 \%$ sangat setuju, $28 \%$ setuju dan $4 \%$ menjawab tidak setuju.

\section{Hasil Telaah Jurnal}

Hasil dari telaah jurnal selama siklus 1 dapat dilihat pada tabel 5 .

Tabel 5. Hasil Telaah Jurnal Guru Siklus I

\begin{tabular}{llllll}
\hline \multirow{2}{*}{ No } & \multicolumn{1}{c}{ Aspek } & \multicolumn{2}{c}{ Aktif } & \multicolumn{2}{c}{ Tidak Aktif } \\
& \% & F & \% & F \\
\hline 1 & Keaktifan peserta didik dalam pembelajaran & $59,4 \%$ & 19 & $40,6 \%$ & 13 \\
2 & $\begin{array}{l}\text { Minat peserta didik selama pembelajaran } \\
\text { berlangsung }\end{array}$ & $71,8 \%$ & 23 & $28,2 \%$ & 9 \\
3 & Respon peserta didik terhadap pembelajaran & $62,5 \%$ & 20 & $37,5 \%$ & 12 \\
4 & Suasana dan situasi kelas & $68,8 \%$ & 22 & $31,2 \%$ & 10 \\
5 & Hambatan yang selama proses pembelajaran & $78,1 \%$ & 25 & $21,9 \%$ & 7 \\
\hline
\end{tabular}

Dari hasil catatan dan pengamatan peneliti diketahui bahwa keaktifan peserta didik dalam pembelajaran sekitar 59,4\% yaitu sekitar 19 peserta didik yang aktif, sedangkan sisanya 13 orang atau 40,6\% tidak aktif. Sedangkan minat siswa selama pembelajaran berlangsung sekitar 23 orang atau sekitar $71,8 \%$ dan sisanya $28,2 \%$ atau 9 peserta didik tidak berminat. Respon peserta didik dalam pembelajaran sekitar $62,5 \%$ sedangkan $31,2 \%$ dari peserta didik tidak antusias terhadap pembelajaran yang berlangsung. Suasana dan situasi kelas kondusif, terbukti dari $73 \%$ atau 19 peserta didik memperhatikan dan tidak ramai sendiri atau main sendiri. Untuk aspek hambatan yang dialami peserta didik cukup masih tinggi. Hampir dari 78,1\% yaitu sekitar 25 dari peserta didik masih belum sepenuhnya percaya diri bila disuruh unjuk kerja di depan kelas. 


\section{Refleksi Siklus 1}

Dari hasil siklus 1 baik hasil tes, observasi, wawancara, angket, telaah jurnal samapi dengan dokumetasi terlihat bahwa apa yang diharapkan belum memenuhi standar. Hal ini dapat dikatakan bahwa hasil refleksi baik dari data tes maupun nontes pada siklus 1 belum mencapaihasilyangmaksimal. Refleksi ini digunakan sebagaiacuan untuk memperbaiki kegiatan padasiklusII,sehingga targetyangdiharapkandapattercapai dengan baik.

\section{Hasil Penelitian SiklusII}

\section{Hasil Tes Siklus II}

Data penilaian tes siklus II dilaksanakan padaakhir proses pembelajaran siklus II yaitu setelah peserta didik melaksanakan pembelajaran dapat dilihat pada Tabel 6.

Tabel 6. Hasil Ulangan Harian Siklus II

\begin{tabular}{|c|c|c|c|c|}
\hline No & Rentang Nilai & $\mathbf{F}$ & Prosentase & Keterangan \\
\hline 1 & $95-100$ & - & - & Dari data disamping dapat \\
\hline 2 & $90-94$ & 1 & $3,12 \%$ & disimpulkan bahwa dengan \\
\hline 3 & $85-89$ & 6 & $18,75 \%$ & KKM IPA 75 , maka kelas \\
\hline 4 & $80-84$ & 13 & $40,60 \%$ & VIII B yang memiliki rata- \\
\hline 5 & $75-79$ & 8 & $25 \%$ & rata $\mathrm{UH}$ siklus $\mathrm{II}=80,5$ \\
\hline 6 & $70-74$ & 1 & $3,12 \%$ & maka dapat diartikan ada \\
\hline 7 & $65-69$ & 2 & $6,25 \%$ & rata-rata nilai \\
\hline 8 & $60-64$ & 1 & $3,12 \%$ & ulangan harian baik secara \\
\hline 9 & $55-59$ & - & - & perorangan maupun klasikal \\
\hline 10 & $50-54$ & - & - & \\
\hline 11 & $45-49$ & - & - & \\
\hline 12 & $40-44$ & - & - & \\
\hline \multirow[t]{5}{*}{13} & $35-39$ & - & - & \\
\hline & Jumlah & 32 & & \\
\hline & Nilai Tertinggi & 90 & & \\
\hline & Nilai Terendah & 60 & & \\
\hline & Nilai Rerata & 80,5 & & \\
\hline
\end{tabular}

Hasil belajar IPA kelas VIII B pada semester II khususnya pada SK 6 yaitu "memahami konsep dan penerapan getaran, gelombang, dan optika dalam produk teknologi sederhana" dan pada KD 6.3 yaitu mendeskripsikan sifat-sifat cahaya dan hubungannya dengan berbagai cermin dan lensa" pada ulangan harian siklus II memiliki rata-rata nilai di atas KKM mata pelajaran IPA yaitu 80,5 atau mengalami kenaikan 7,3\%. Dari 32 peserta didik yang mengikuti ulangan harian siklus II yang mendapatkan nilai sama dengan atau lebih besar dari KKM mata pelajaran IPA adalah 28 peserta didik atau 80,5\% yang tuntas, sedangkan masih terdapat 4 peserta didik yang belum tuntas yaitu $12,5 \%$. Dengan adanya kenaikan rata-rata nilai 7,3 \% dari KKM IPA maka peneliti dapat menyimpulkan bahwa pada siklus II lebih meningkat dari pada siklus I. 


\section{Hasil Nontes Siklus II}

Pada siklus II data non didapat dari hasil observasi, angket, jurnal kelas, jurnal guru, wawancara, dan dokumentasi foto .

\section{Hasil Observasi}

Hasil observasi siklus II dapat di lihat pada Tabel 7.

Tabel 7 . Hasil Observasi Kreativitas Belajar IPA Siklus II

\begin{tabular}{|c|c|c|c|c|}
\hline \multirow{2}{*}{ Aspek } & \multicolumn{2}{|c|}{ Aktif } & \multicolumn{2}{|c|}{ Tidak Aktif } \\
\hline & $\%$ & $\mathbf{F}$ & $\%$ & $\mathbf{F}$ \\
\hline 1. Perhatian dan respon peserta didik & $90 \%$ & 29 & $10 \%$ & 3 \\
\hline 2. Aktif dalam diskusi & $75 \%$ & 24 & $25 \%$ & 8 \\
\hline 3. Aktif bertanya & $78 \%$ & 25 & $22 \%$ & 7 \\
\hline 4. Berani dan tidak canggung saat presentasi & $78 \%$ & 25 & $22 \%$ & 7 \\
\hline 5. Menghargai kelompok lain dalam diskusi & $84 \%$ & 27 & $16 \%$ & 5 \\
\hline
\end{tabular}

BerdasarkanTabel 7 dapat diketahui bahwa perhatian dan respon peserta didik semakin meningkat, yaitu sebanyak 29 orang atau sebesar 90\%, sedangkan sisanya10\%atau sebanyak 3 orang dari jumlah peserta didik yang tidak aktif. Untuk aspek aktif dalam diskusi peserta didik yang aktif sebanyak 24 peserta didik atau 75\%, sedangkan sisanya sebesar 8 peserta didik atau $25 \%$ tidak aktif. Untuk aspek aktif bertanya peserta didik terhadap teknik yang digunakan sebesar 25 atau $78 \%$, sedangkan peserta didik yang tak acuh terhadap metode yang digunakan guru sebesar 7 peserta didik atau 22\%. Untuk aspek berani dan tidak canggung saat presentasi sebanyak 23 peserta didik atau sebesar $71 \%$, sedangkan peserta didik yang tidak aktif sebanyak 9 peserta didik atau sebesar $29 \%$. Untuk aspek menghargai kelompok lain yang maju sebanyak 27 peserta didik atau 84\%, sedangkan peserta didik yang tidak respons terhadap kelompok lain sebanyak 5 peserta didik atau sebesar $16 \%$.

\section{Hasil wawancara}

Hasil wawancara pada peserta yang selama ini tidak berani bila tampil ke depan kelas, bertanya, atau mengemukakan pendapat, sekarang menjadi berani. Mereka lebih percaya diri karena pembelajarannya menjadi lebih menyenangkan dan tidak terkesan kaku ataupun menegangkan.

\section{Hasil Angket}

Hasil angket akhir pembelajaran pada siklus II,ditunjukkan pada Tabel 8.

Tabel 8 . Hasil Angket Tanggapan Peserta Didik Siklus II

\begin{tabular}{llllll}
\hline \multirow{2}{*}{ No } & \multirow{2}{*}{ Pernyataan } & \multicolumn{4}{c}{ Tanggapan peserta didik } \\
& & SS & S & TS & TT \\
\hline
\end{tabular}




\begin{tabular}{|c|c|c|c|c|c|}
\hline 1 & $\begin{array}{l}\text { Pembelajaran IPA dengan model kooperatif } \\
\text { tipe think, pair, shara (TPS) seperti yang } \\
\text { sudah dilaksanakan sangat menarik dan } \\
\text { menyenangkan. }\end{array}$ & $90 \%$ & $10 \%$ & 0 & 0 \\
\hline 2 & $\begin{array}{l}\text { Dengan pembelajaran model kooperatif } \\
\text { saya menjadi berani untuk maju, dan } \\
\text { bertanya tentang materi IPA. }\end{array}$ & $87,5 \%$ & $12,5 \%$ & 0 & 0 \\
\hline 3 & $\begin{array}{l}\text { Dengan pembelajaran model kooperatif } \\
\text { saat dalam kelompok saya menjadi berani } \\
\text { melakukan presentasi di depan teman- } \\
\text { teman sekelas. }\end{array}$ & $78,2 \%$ & $21,8 \%$ & 0 & 0 \\
\hline 4 & $\begin{array}{l}\text { Dengan pembelajaran model kooperatif saya } \\
\text { menjadi memiliki tanggung jawab ketika } \\
\text { mengerjakan tugas baik sendiri atau } \\
\text { berkelompok. }\end{array}$ & $84,4 \%$ & $15,6 \%$ & 0 & 0 \\
\hline 5 & $\begin{array}{l}\text { Saat ini saya sudah tidak lagi merasa malu } \\
\text { atau takut untuk maju atau bertanya saat } \\
\text { pembelajaran IPA berlangsung. }\end{array}$ & $81,3 \%$ & $12,5 \%$ & $6,25 \%$ & 0 \\
\hline
\end{tabular}

Berdasarkan Tabel 8 tersebut dapat diketahui bahwa pernyataan yang menjelaskan pembelajaran IPA dengan model kooperatif tipe TPS seperti yang sudah dilaksanakan sangat menarik dan menyenangkan. Peserta didik yang sangat setuju sebanyak 29 orang atau sebesar $90 \%$ dari 32 peserta didik, sedangkan yang setuju 10\% atau sebanyak 3 orang. Untuk aspek dengan pembelajaran model kooperatif peserta didik menjadi berani untuk maju dan bertanya tentang materi IPA. Peserta didik yang sangat setuju sebanyak 28 orang atau $87,5 \%$, sedangkan yang setuju sebanyak 4 orang atau $12,5 \%$ dan tidak setuju tidak ada. Untuk aspek dengan pembelajaran model kooperatif saat dalam kelompok peserta didik menjadi berani melakukan presentasi di depan teman-teman sekelas. Peserta didik yang sangat setuju sebanyak 25 orang atau $78,2 \%$, sedangkan peserta didik setuju sebanyak 7 orang atau $21,8 \%$. Untuk aspek dengan pembelajaran model kooperatif peserta didik menjadi memiliki tanggung jawab ketika mengerjakan tugas baik sendiri atau berkelompok. Peserta didik yang setuju sebanyak 27 orang atau sebesar $84,4 \%$, sedangkanpeserta didik setuju sebanyak 5 orang atau sebesar 15,6\%. Untuk aspek peserta didik sudah tidak lagi merasa malu atau takut untuk maju atau bertanya saat pembelajaran IPA berlangsung. Peserta didik yang sangat setuju sebanyak 26 orang atau sebesar $81,3 \%$, sedangkan peserta didik yang setuju sebanyak 4 orang atau sebesar $12,5 \%$. Ternyata diketahui masih ada peserta didik yang mengalami kesulitan atau takut bertanya atau malu untuk maju di depan kelas yaitu sekitar 2 orang atau sebesar $6,25 \%$.

\section{Hasil Telaah Jurnal}

Hasil telaah jurnal yang dilakukan pada akhir pembelajaran ditunjukkan Tabel 9.

Tabel 9. Hasil Telaah Jurnal Guru Siklus II

\begin{tabular}{llllll}
\hline \multirow{2}{*}{ No } & \multirow{2}{*}{ Aspek } & \multicolumn{3}{c}{ Aktif } & \multicolumn{2}{c}{ Tidak Aktif } \\
& & $\%$ & F & $\%$ & F \\
\hline
\end{tabular}




\begin{tabular}{llcccc}
\hline 1 & Keaktifan peserta didik dalam pembelajaran & $81,3 \%$ & 26 & $18,7 \%$ & 6 \\
2 & Minat siswa selama pembelajaran berlangsung & $87,5 \%$ & 28 & $12,5 \%$ & 4 \\
3 & Respon siswa terhadap pembelajaran & $90,6 \%$ & 29 & $9,3 \%$ & 3 \\
4 & Suasana dan situasi kelas & $81,3 \%$ & 26 & $18,7 \%$ & 6 \\
5 & Hambatan yang dialami selama proses & $84,3 \%$ & 27 & $15,7 \%$ & 5 \\
\hline
\end{tabular}

Dari hasil catatan dan pengamatan peneliti diketahui bahwa keaktifan peserta didik dalam pembelajaran siklus II menjadi81,3\% yaitu sekitar 26 peserta didik yang aktif, dan masih terdapat 7 peserta didik atau $18,7 \%$ yang tidak aktif. Untuk minat selama pembelajaran berlangsung terdapat 28 peserta didik atau sekitar $87,5 \%$ yang baik,sedangkan terdapat $12,5 \%$ atau 4 peserta didik yang kurang berminat. Respon peserta didik dalam pembelajaran sekitar 90,6\% atau 29 peserta didik sangat respons, sedangkan 9,3\% atau 3 peserta didik tidak antusias terhadap pembelajaran yang berlangsung. Suasana dan situasi kelas kondusif, terbukti dari 81,3\% atau 26 peserta didik memperhatikan dan tidak ramai sendiri atau main sendiri dan masih ada peserta didik yang kurang perhatian terhadap proses pembelajaran yaitu $18,7 \%$ atau 8 peserta didik. Untuk aspek hambatan yang dialami peserta didik cukup masih tinggi. Untuk hambatan dalam pembelajaran ada 15,7\% atau 5 peserta didik yang tidak serius, atau mengganggu peserta didik lain selama proses pembelajaran.

\section{Refleksi Siklus II}

Refleksi pada siklus II dilakukan untuk perbaikan proses pembelajaran pada siklus I sebelumnya. Setelah pelaksanaan tindakan siklus II, peneliti melakukan analisis terhadap hasil tes, hasil observasi, hasil jurnal, dan hasil wawancara yang telah dilakukan. Analisis ini bertujuan untuk mengetahui seberapa besar peningkatan hasil belajar IPA pada meteri cahaya dan untuk mengetahui seberapa besar perubahan perilaku peserta didik setelah diberi pembelajaran dengan menggunakan model kooperatif tipe TPS.

Pembelajaran IPA pada materi Cahaya menggunakan model pembelajaran kooperatif tipe TPS pada siklus II menjadikan peserta didik sangat antusias. Hali ni disebabkan peserta didik sudah mengetahui model kooperatif tipe TPS yang sudah diberikan pada siklus I. Pada pembelajaran siklus II ini, hanya ada beberapa peserta didik yang masih memiliki rasa malu bila maju melakukan presentasi di depan kelas atau bertanya. Nilai rata-rata kelas pada siklus II sudah mencapai batas diatas KKM IPA yaitu 80,5.

Pada data non tes siklus II yang berupa hasil observasi, angket dan telaah jurnal dapat diketahui bahwa peserta didik suka dengan pembelajaran yang dilakukan oleh guru/peneliti dengan menggunakan model kooperatif tipe TPS. Hal ini membuktikan bahwa pembelajaran sudah mencapai hasil yang diharapkan, sehingga peneliti tidak lagi melakukan tindakan berikutnya. 


\section{Pembahasan}

Pembahasan hasil yang terakhir pada penelitian ini didasarkan pada hasil penelitian yang telah diperoleh pada siklus I dan siklus II. Hasil penelitian ini digunakan untuk mengukur seberapa besar peningkatan hasil belajar dan kreatifitas pada peserta didik kelas VIII B SMP Negeri 1 Jambu Kabupaten Semarang, semester II tahun pelajaran 2012/2013. Pembahasan hasil tes mengacu pada perolehan skor yang dicapai oleh peserta didik.

Adapun perubahan perilaku belajar diperoleh dari hasil perolehan skor non tes. Hasil non tes didasarkan pada lima buah instrumen non tes, yaitu: (1) observasi, (2) wawancara, (3) angket, (4) jurnal, dan (5) dokumentasi foto. Hasil tes dan nontes pada pembahasan ini dibahas secara terpisah sebagai berikut.

\section{Peningkatan Hasil Belajar dan Kreatifitas}

Pada penelitian ini, hasil belajar setelah menggunakan model kooperatif tipe TPS dapat mencapai batas tuntas klasikal. Tuntas secara klasikal artinya, jumlah peserta didik yang tuntas belajar dengan nilai 75 atau diatasnya mencapai 28 peserta didik atau 80,5\% dari 32 peserta didik kelas VIII B. Adapun hasil penelitian ini dapat dilihat pada tabel 10.

Tabel 10. Perbandingan Hasil Tes Siklus I dan Siklus II

\begin{tabular}{cccccccc}
\hline \multirow{2}{*}{ No } & Rentang & \multicolumn{3}{c}{ Hasil Tes } & \multicolumn{3}{c}{ Ketuntasan (\%) } \\
& Nilai & Prasiklus & S I & S II & Prasiklus & S I & S II \\
\hline 1 & $90-100$ & 3 & 1 & 1 & 72,2 & 74,4 & 80,5 \\
2 & $80-89$ & 9 & 13 & 19 & & & \\
3 & $70-79$ & 8 & 9 & 9 & & & \\
4 & $40-69$ & 12 & 9 & 3 & & & \\
5 & $0-39$ & - & - & - & & & \\
& Jumlah peserta & 32 & 32 & 32 & 32 & 32 & 32 \\
\hline
\end{tabular}

Berdasarkan tabel 10 terlihat bahwa hasil belajar peserta didik dalam pembelajaran IPA menggunakan model kooperatif tipe think, pair, share membawa dampak pada kenaikan hasil belajar peserta didik daripada sebelaum menggunakan model kooperatif atau menggunakan model ceramah. Kegiatan ulangan harian yang diadakan oleh guru untuk mengetahui peningkatan hasil belajar terlihat mulai dari prasiklus, siklus I, dan siklus II yang mengalami perubahan rata-rata nilai.

Pada pra siklus hasil belajar peserta didik masih berada dibawah KKM IPA, ini membuktikan bahwa pembelajaran dengan model ceramah pada materi Cahaya belum berhasil mengangkat hasil belajar peserta didik. Sedangkan pada siklus I rata-rata ulangan harian peserta didik mengalami peningkatan tetapi masih di bawah KKM mata pelajaran IPA. Hal ini dapat dijelaskan karena peserta didik baru pertama mengalami pembelajaran menggunakan model yang berbeda, yang melibatkan 
peserta didik secara keseluruhan dan diakhiri dengan presentasi di depan kelas.

Pada siklus II, hasil belajar peserta didik menggunakan model kooperatif JPS. Puga mengalami peningkatan yaitu rata-rata hasil belajar IPA pada materi Cahaya sudah diatas KKM IPA yaitu 80,5.

Dengan demikian model pembelajaran IPA pada materi Cahaya dengan model kooperatif tipe think, pair, share dapat meningkatkan hasil belajar peserta didik kelas VIII B semester II tahun pelajaran 2012/2013 SMP Negeri 1 Jambu Kabupaten Semarang.

\section{Perubahan Prilaku Belajar Peserta Didik.}

Perubahan prilaku peserta didik pada siklus I dan siklus II teramati melalui kegiatan observasi ditunjukkan Tabel 11.

Tabel 11. Hasil Observasi Kreativitas Belajar IPA Siklus I dan Siklus II

\begin{tabular}{|c|c|c|c|c|c|c|c|c|}
\hline \multirow[b]{2}{*}{ Aspek } & \multicolumn{4}{|c|}{ SIKLUS I } & \multicolumn{4}{|c|}{ SIKLUS II } \\
\hline & Aktif & $\mathbf{F}$ & $\begin{array}{l}\text { Tidak } \\
\text { Aktif }\end{array}$ & $\mathbf{F}$ & Aktif & $\mathbf{F}$ & $\begin{array}{l}\text { Tidak } \\
\text { Aktif }\end{array}$ & $\mathbf{F}$ \\
\hline $\begin{array}{l}\text { 1. Perhatian dan respon } \\
\text { peserta didik }\end{array}$ & $73 \%$ & 23 & $\begin{array}{l}27 \\
\%\end{array}$ & 9 & $90 \%$ & 29 & $10 \%$ & 3 \\
\hline 2. Aktif dalam diskusi & $63 \%$ & 20 & $\begin{array}{l}37 \\
\%\end{array}$ & $\begin{array}{l}1 \\
2\end{array}$ & $75 \%$ & 24 & $25 \%$ & 8 \\
\hline 3. Aktif bertanya & $65 \%$ & 21 & $\begin{array}{l}35 \\
\%\end{array}$ & 11 & $78 \%$ & 25 & $22 \%$ & 7 \\
\hline $\begin{array}{l}\text { 4. Berani dan tidak } \\
\text { canggung saat presentasi }\end{array}$ & $56 \%$ & 18 & $\begin{array}{l}44 \\
\%\end{array}$ & 14 & $78 \%$ & 25 & $22 \%$ & 7 \\
\hline $\begin{array}{l}\text { 5. Menghargai kelompok } \\
\text { lain dalam diskusi }\end{array}$ & $75 \%$ & 24 & $\begin{array}{l}25 \\
\%\end{array}$ & 8 & $84 \%$ & 27 & $16 \%$ & 5 \\
\hline
\end{tabular}

Hasil observasi pembelajaran tentang kreatifitas peserta didik pada siklus I menunjukkan kenaikan yang signifikan pada siklus II. Hal ini dapat dilihat dari tabel bahwa respons, kreaktifan, berani mewakili kelompok dalam diskusi, serta menghargai kelompok lain dalam diskusi secara keseluruhan mengalami kenaikan. Peserta didik yang tidak aktif dalam siklus I mengalami penurunan pada siklus II, hal ini juga menunjukkan bahwa menggunakan model pembelajaran kooperatif tipe TPS dapat meningkatkan kreatifitas peserta didik dalam pembelajaran.

Tabel 12. Hasil Angket Tanggapan Peserta Didik Siklus I dan Siklus II

\begin{tabular}{|c|c|c|}
\hline \multirow[b]{3}{*}{ No } & \multirow[b]{3}{*}{ Pernyataan } & Tanggapan peserta didik \\
\hline & & SIKLUIS II \\
\hline & & 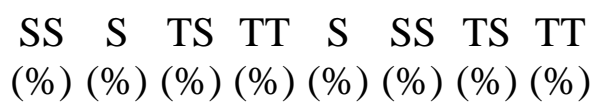 \\
\hline 1 & $\begin{array}{l}\text { Pembelajaran IPA dengan model kooperatif } \\
\text { tipe think, pair, share (TPS) seperti yang } \\
\text { sudah dilaksanakan sangat menarik dan } \\
\text { menyenangkan. }\end{array}$ & $\begin{array}{llllllll}62 & 38 & 0 & 0 & 90 & 10 & 0 & 0\end{array}$ \\
\hline
\end{tabular}


2 Dengan pembelajaran model kooperatif saya menjadi berani untuk maju, dan bertanya tentang materi IPA.

3 Dengan pembelajaran model kooperatif saat dalam kelompok saya menjadi berani melakukan presentasi di depan temanteman sekelas.

4 Dengan pembelajaran model kooperatif saya menjadi memiliki tanggung jawab ketika mengerjakan tugas baik sendiri atau berkelompok.

5 Saat ini saya sudah tidak lagi merasa malu atau takut untuk maju atau bertanya saat pembelajaran IPA berlangsung. $\begin{array}{lllllll}68 & 28 & 4 & 0 & 87,512,5 & 0 & 0\end{array}$

$\begin{array}{lllllll}52 & 48 & 0 & 0 & 78,221,8 & 0 & 0\end{array}$

$\begin{array}{lllllll}70 & 30 & 0 & 0 & 84,415,6 & 0 & 0\end{array}$

$\begin{array}{llllll}64 & 25 & 8 & 3 & 81,312,56,25 & 0\end{array}$

Dari tabel 12 terlihat bahwa tanggapan peserta didik pada siklus I tentang : pembelajaran IPA dengan model kooperatif tipe Think, pair, share, keberanian peserta didik untuk bertanya, bertanggung jawab terhadap tugas yang diberikan guru, merasa tidak canggung dan tidak takut saat beraktifitas mengalami kenaikan pada siklus II.

Dalam telaah jurnal perubahan prilaku peserta didik juga mengalami peningkatan. Hal ini dapat dilihat dari tabel hasil dari telaah jurnal siklus I dan siklus II.

Tabel 13. Perubahan Perilaku Peserta Didik setelah Mengikuti Pembelajaran Siklus I dan Siklus II dari Hasil Telaah Jurnal

\begin{tabular}{llcccc}
\hline \multirow{2}{*}{ No } & \multirow{2}{*}{ Aspek } & \multicolumn{2}{c}{ Aktif } & \multicolumn{2}{c}{ Tidak Aktif } \\
& & S I $(\%)$ & S II $(\%)$ & S I $(\%)$ & S II $(\%)$ \\
\hline 1 & Keaktifan & 59,4 & 81,3 & 40,6 & 18,7 \\
2 & Minat & 71,8 & 87,5 & 28,2 & 12,5 \\
3 & Respon & 62,5 & 90,6 & 37,5 & 9,3 \\
4 & Suasana dan situasi kelas & 68,8 & 81,3 & 31,2 & 18,7 \\
5 & Hambatan dalam pembelajaran & 78,1 & 84,3 & 21,9 & 15,7 \\
\hline
\end{tabular}

Dari tabel 13 perubahan prilaku dengan telaah jurnal yang dilakukan oleh peneliti dapat disimpulkan bahwa peserta didik setelah mengikuti pembelajaran dengan menggunakan model kooperatif tipe TPS terjadi perubahan tingkah laku yaitu keaktifan, minat, serta respons saat mengikuti pembelajaran meningkat, sedang peserta didik yang tidak aktif mengalami penurunan setelah mengukti pembelajaran menggunakan model kooperatif tipe TPS.

Sedangkan situasi kelas, serta hambatan selama proses pembelajaran berlangsung menjadi terkendali artinya peserta didik yang selama pembelajaran sering asyik dengan kegiatannya sendiri menjadi berkurang. 


\section{KESIMPULAN}

Dari hasil penelitian dan pembahasan dapat disimpulkan bahwa:

1. Penggunaan model kooperatif tipe TPS dapat meningkatkan kreatifitas dan hasil belajar peserta didik kelas VIII B SMP Negeri 1 Jambu Semester 2 tahun pelajaran 2012/2013.

2. Penggunaan model kooperatif tipe TPS dapat mengubah prilaku belajar peserta didik kelas VIII B SMP Negeri 1 Jambu Semester 2 tahun pelajaran 2012/2013 pada materi cahaya. Hal ini terlihat hingga akhir siklus II jumlah peserta didik yang mendapatkan nilai diatas KKM lebih dari 80\% dari jumlah seluruh peserta didik. 


\section{DAFTAR PUSTAKA}

Kasbolah, 1999 . Penelitian Tindakan Kelas untuk Guru Sains. Makalah disajikan dalam Pelatihan Guru Sains dengan Pendekatan STM.

Malang, 12 - 15 Juli 1999.

Munandar,S.C.Utami,1992. Mengembangkan Bakat dan Kreativitas anak sekolah : penuntun bagi para guru dan orang tua. Jakarta : Grasindo.

Munandar,S.C.Utami, 1985. Mengembangkan Bakat dan Kreativitas anak sekolah : penuntun bagi para guru dan orang tua. Jakarta : Gramedia Pustaka Utama.

Susilo,Herawati, Husnul Chotimah, Yuyun Dwita Sari,2008. Penelitian Tindakan Kelas sebagai sarana Pengembangan Keprofesionalan Guru dan Calon Guru. Edisi ke 1. Malang : Bayumedia Publishing.

Sukarno, 2001. Dasar-dasar Pendidikan Sains, Jakarta : Bhratara karya Aksara.

Sanjaya,W, 2007. Strategi Pembelajaran Berorientasi Standar Proses Pendidikan. Edisi ke 2. Jakarta : Kencana Prenada Media grup.

.2009. Pendidikan dan Latihan Profesi Guru (PLPG) Sertifikasi Guru dalam Jabatan.

PP Nomor 19 tahun 2005 tentang Standar nasional Pendidikan2003.Depdiknas, Dirjen Pendidikan Dasar dan Menengah Direktorat Pendidikan Lanjutan Pertama.

http://ads.masbuchin.com/search/pembelajaran+kooperatif +think+ pair+ share diundih (22 Februari $\underline{2009)}$ 